\title{
PENGARUH PENGUNGKAPAN AKUNTANSI LINGKUNGAN DAN MEKANISME GOOD CORPORATE GOVERNANCE TERHADAP KINERJA KEUANGAN PADA PERUSAHAAN MANUFAKTUR YANG TERDAFTAR DI BURSA EFEK INDONESIA
}

\author{
Dinal Eka Pertiwi ${ }^{1}$, Ahmad Junaidi ${ }^{2}$, Furqonti Ranidiah ${ }^{3}$, Nensi Yuniarti. Zs $^{4}$, Kiki Permata \\ Sari $^{5}$ \\ ${ }^{12345}$ Universitas Muhammadiyah Bengkulu \\ dinalekapertiwi@umb.ac.id ${ }^{1}$, ahmadjunaidi@umb.ac.id ${ }^{2}$, furqontiranidiah@umb.ac.id, \\ nensiyuniarti@umb.ac.id, kikipermata351@gmail.com ${ }^{3}$
}

\begin{abstract}
ABSTRAK
Penelitian ini menggunakan metode purposive sampling, dengan jumlah perusahaan 29 × 3 tahun penelitian dan total sampel 87. Metode statistik yang digunakan adalah SPSS regresi linear berganda, dengan pengujian hipotesis uji statistik $\mathrm{T}$ parsial, uji $\mathrm{F}$ simultan dan uji koefisien determinasi. Hasil dari penelitian ini menyatakan bahwa: Pengungkapan Akuntansi Lingkungan berpengaruh negatif terhadap Kinerja Keuangan, dengan nilai sig 0,361. Kepemilikan Institusional berpengaruh negatif terhadap Kinerja Keuangan, dengan nilai sig 0,980. kepemilikan manajerial berpengaruh positif signifikan terhadap Kinerja Keuangan, dengan nilai sig 0,041. Komite Audit berpengaruh positif dan signifikan terhadap Kinerja Keuangan, dengan nilai sig 0,011. Pengungkapan akuntansi lingkungan, kepemilikan Institusional, kepemilikan manajerial, Komite Audit, dengan nilai sig 0,021.
\end{abstract}

Kata Kunci : Pengungkapan Akuntansi Lingkungan, Kepemilikan Institusional, Kepemilikan Manajerial, Komite Audit dan Kinerja Keuangan.

\begin{abstract}
This research uses purposive sampling method, with the number of companies $29 \times 3$ years of research and a total sample of 87. The statistical method used is SPSS multiple linear regression, with partial $t$ statistical test hypothesis testing, simultaneous $f$ test and coefficient of determination test. The results of this study state that: environmental accounting disclosures has a negative effect on financial performance, with a sig value of 0,361. Institutional ownership has a negative effect on financial performance, with a sig valeu of 0,980. Managerial ownership has a positive effect on financial performance, with a sig value of 0,041. The audit committee has a positive and significant effech on financial performance, with a sig valeu of 0,011. Disclosure of environmental accounting, Institutional ownership, Managerial ownership, audit committee, with a sig value of 0,021.
\end{abstract}

Keywords : Environmental Accounting, Institutional Ownership, Managerial Ownership, Audit Committee and Financial Performance 


\section{PENDAHULUAN}

Perusahaan yang berorientasi pada laba akan berusaha menggunakan sumber daya yang dimilikinya semaksimal mungkin untuk memperoleh laba demi kelangsungan hidupnya sehingga berakibat pada dampak lingkungan baik secara positif maupun secara negatif. Dampak negatif yang paling sering muncul ditemukan dalam setiap adanya penyelenggaraan operasional usaha perusahaan adalah polusi suara, limbah produksi, kesenjangan, dan lain sebagainya dan dampak semacam inilah yang dinamakan eksternality. Besarnya dampak eksternalities ini terhadap kehidupan masyarakat yang menginginkan manfaat perusahaan menyebabkan timbulnya keinginan untuk melakukan kontrol terhadap apa yang dilakukan oleh perusahaan secara tersistematis sehingga dampak negatif dari eksternalities ini tidak menjadi semakin besar dan meluas. Persoalan lingkungan semakin meluas dan semakin menarik untuk di kaji seiring perkembangan teknologi dan ekonomi global dunia. Akuntansi lingkungan merupakan pencegahan, pengurangan dan atau penghindaran dampak terhadap lingkungan, bergerak dari beberapa kesempatan di mulai dari perbaikan kembali kejadian-kejadian yang menimbulkan bencana atas kegiatan-kegiatan tersebut. Jadi konsep akuntansi lingkungan bagi perusahaan adalah kemampuan perusahaan untuk meminimalisasi persoalan-persoalan lingkungan yang dihadapinya (Tarmizi, 2012).

Keadaan lingkungan di dunia termasuk di Indonesia saat ini memprihatinkan, dan salah satu masalah lingkungan hidup adalah pemanasan global (global warming). Global Warming semakin mengemuka seiring dengan maraknya kasus pencemaran lingkungan, di Indonesia terdapat permasalahan lingkungan akibat proses produksi perusahaan yaitu PT. Lapindo Brantas dan PT. Newmont Minahasa Raya. Kegiatan pengeboran oleh PT. Lapindo yang menyebabkan tidak stabilnya kondisi tanah dibawah lokasi awal yang berakibat pada menyemburnya lumpur dan diperparah dengan terjadinya semburan gas metana disertai air bercampur lumpur. PT. Newmont Minahasa Raya juga pernah melakukan pencemaran lingkungan di Teluk Buyat, Kabupaten Bolaang Mongondow, Sulawesi Utara. Tim Ahli dari Universitas Sam Ratulangi menyatakan Newmont terbukti membuang tailing yang mengandung bahan beracun berbahaya(B3) di Teluk Buyat dengan konsentrasi merkuri dan arsenik dalam air. Oleh karena itu, untuk meminimalisasi kondisi ini diperlukan mekanisme yang akan menyamakan atau menyejajarkan kepentingan antara prinsipal dan agen tersebut. Salah satu mekanisme yang dapat dilakukan adalah tata kelola perusahaan yang baik atau Good Corporate Governance (GCG). http://id.m.wikipedia.org/wiki/Lapindo_Brantas_Inc

Pengungkapan akuntansi lingkungan berpengaruh signifikan terhadap kinerja keuangan (Return on Assets) dalam penelitian yang dilakukan (Ekaputri, M. N. R. Lestari, R., Rosdiana, Y., \& Fitriah, 2018) yang berjudul Kontribusi Pengungkapan Akuntansi Lingkungan Dan Mekanisme GCG Terhadap Kinerja Keuangan, berbeda dengan penelitian yang dilakukan Jayanti (2015) dengan judul penelitian pengaruh pengungkapan informasi akuntansi lingkungan terahadap kinerja keuangan perusahaan terdapat pengaruh negatif signifikan dari pengungkapan akuntansi lingkungan terhadap kinerja keuangan yang diproksikan denganreturn on assets ( ROA). Menurut (Arifani, 2012) Mekanisme Good Corporate Governance (GCG) merupakan suatu sistem yang mengatur hubungan antara pihak-pihak yang berkepentingan (stakeholders) demi tercapainya tujuan organisasi. Hubungan-hubungan ini digambarkan dalam beberapa indikator komite audit, kualitas audit, kepemilikan institusional, komisaris independen dan kepemilikan manajerial.

Ekaputri, M. N. R. Lestari, R., Rosdiana, Y., \& Fitriah, (2018) menyatakan bahwa mekanisme good corporate governance yang diproksikan dengan dewan komisaris, dewan direksi dan komite audit tidak berpengaruh signifikan terhadap kinerja keuangan. Dalam penelitian lain yang dilakukan oleh (Andri Veno, 2015) yang mana hasil penelitian yang diproksikan dengan direksi, komisaris independen, total komisaris dan komite audit berpengaruh secara bersama-sama terhadap kinerja keuangan yang diproksikan dengan Return on Equity (ROE). 


\section{TINJAUAN PUSTAKA}

\section{Teori Keagenan (Agency Theory)}

Teori ini menurut (Sri Rokhlinasari, 2016) mengatakan hubungan antara prinsipal (principal) dan agen (agent) yang di dalamnya agen bertindak atas nama dan untuk kepentingan prinsipal dan atas tindakannya (action) tertentu agen mendapatkan imbalan (Suwardjono, 2014:485). Pada saat pemegang saham menunjuk manajer atau agen sebagai pengelola dan pengambil keputusan bagi perusahaan maka pada saat itulah hubungan keagenan muncul (Handayati, 2017) dengan cara memberikan kepercayaan kepengurusan kepada agen pastinya akan menimbulkan asimetri informasi diantara agen dan prinsipal atau pemegang saham serta akan menimbulkan konflik kepentingan dalam hubungan keagenan.

Terjadinya konflik kepentingan antara pemilik dan agen karena kemungkinan agen bertindak tidak sesuai dengan kepentingan prinsipal sehingga dapat meminimumkan konflik keagenan. Asimetri informasi antara manajemen (agent) dengan pemilik (principal) dapat memberikan kesempatan kepada manajer untuk melakukan tindakan oportunistis seperti manajemen laba (earning management) kinerja ekonomi perusahaan sehingga dapat merugikan pemegang saham (Rokhlinasari, 2016) dengan penerapan good corporate governance di dalam sebuah perusahaan akan mengurangi dampak asimetri informasi dan konflik kepentingan antara agen dan prinsipal. Konsep good corporate governance bertujuan untuk menjadikan perusahaan menjadi lebih sehat. Teori keagenan lebih menekankan pada penentuan kontrak yang jelas untuk masing-masing pihak yang berisi tentang hak dan kewajiban, good corporate governance merupakan suatu mekanisme pengelolaan yang didasarkan pada teori keagenan

\section{Teori Legitimasi}

Teori Legitimasi Menurut (Sri Rokhlinasari, 2016) teori legitimasi adalah teori yang menyatakan bahwa organisasi secara berkelanjutan mencari cara untuk menjamin operasi mereka berada dalam batas dan norma yang berlaku di masyarakat.

Legitimasi merupakan suatu keadaan psikologis keberpihakan orang dan kelompok orang yang sangat peka terhadap gejala lingkungan sekitar baikfisik maupun non fisik. Beberapa studi tentang pengungkapan akuntansi lingkungan dan sosial menggunakan teori legitimasisebagai basis dalam menjelaskan praktik pengungkapan lingkungan.

Adanya teori legitimasi memberikan landasan bahwa perusahaan harus menaati normanorma yang berlaku di dalam masyarakat dimana perusahaan berada agar operasi perusahaan juga dapat berjalan lancar tanpa adanya konflik dengan masyarakat sekitar (Ekaputri, M. N. R. Lestari, R., Rosdiana, Y., \& Fitriah, 2018) kepedulian terhadap lingkungan operasi harus dilakukan secara berkelanjutan agar terciptanya kepercayaan dalam hubungan dengan masyarakat dan keberlanjutan sebuah perusahaan. Untuk menjaga hal tersebut bisa dilakukan dengan cara pengungkapan dalam laporan tahun perusahaan atau bahkan membuat satu laporan khusus yang berkaitan dengan lingkungan dan sosial, dengan cara ini para stakeholders termasuk masyarakat bisa melihat dan melakukan penilaian terhadap perusahaan serta dapat menerima keberadaan perusahaan dengan baik.

\section{Pengungkapan akuntansi lingkungan}

Menurut (Suartana, 2010) Pengungkapan Akuntansi lingkungan merupakan salah satu istilah yang digunakan perusahaan untuk mengungkapkan pengelompokan pembiayaan mengenai konservasi lingkungan. Kata pengungkapan memiliki arti tidak menutupi atau tidak menyembunyikan. Apabila dikaitkan dengan data,pengungkapan berarti memberikan data yang bermanfaat kepada pihak yang memerlukan. Jadi data tersebut harus benar-benar bermanfaat,karena apabila tidak bermanfaat, tujuan dari pengungkapan tersebut tidak akan tercapai. Pengungkapan ada 2 jenis yaitu pengungkapan wajib (mandatory disclosure) dan pengungkapan sukarela (voluntary disclosure). Pengungkapan wajib merupakan pengungkapan minimum yang harus diungkapkan (diwajibkan peraturan). Sedangkan pengungkapan sukarela 
merupakan pengungkapan yang tidak diwajibkan peraturan, dimana perusahaan bebas memilih jenis informasi apa yang sekiranya dapat mendukung dalam pengambilan keputusan.

Faktor-faktor yang mempengaruhi pengungkapan Akuntansi Lingkungan.

Dalam pengungkapan Akuntansi Lingkungan, perusahaan harus terlebih dahulu menerapkan sistem Akuntansi Lingkungan. Penerapan Akuntansi Lingkungan dipengaruhi oleh beberapa faktor. Faktor-faktor ini juga yang nantinya akan mempengaruhi pengungkapan akuntansi lingkungan. Faktor-faktor tersebut adalah kepemilikan manajemen, tingkat leverage, size perusahaan, dan profitabilitas.

1. Kepemilikan Manajemen dapat diartikan sebagai proporsi saham biasa yang di miliki manajemen. Manajemen yang memiliki saham perusahaan tentunya akan menselaraskan kepentingannya dengan kepentingan sebagai pemegang saham. Sementara manajer yang tidak memiliki saham perusahaan, ada kemungkinan hanya mementingkan kepentingannya sendiri.

2. Tingkat Rasio Leverage merupakan proporsi total hutang terhadap ekuitas pemegang saham. Rasio tersebut digunakan untuk memberikan gambaran mengenai struktur modal yang dimiliki perusahaan, sehingga dapat dilihat tingkat resiko tak tertagihnya suatu hutang.

3. Size perusahaan merupakan variabel yang paling banyak di gunakan untuk menjelaskan pengungkapansocial yang di lakukan perusahaan dalam mengungkapkan laporan tahunan yang di buat.

\section{Mekanisme goodcorporate governance}

Menurut (Arifani, 2012) Mekanisme Good Corporate Governance (GCG) merupakan suatu sistem yangmengatur hubungan antara pihak-pihak yang berkepentingan (stakeholders) demi tercapainya tujuan organisasi. Hubungan-hubungan ini digambarkan dalam beberapa indikator komite audit, kualitas audit, kepemilikan institusional, komisaris independen dan kepemilikan manajerial.

\section{Kinerja keuangan}

Menurut (Sarafina dan Saifi, 2017), kinerja keuangan merupakan patokan utama untuk mengukur baik atau tidaknya kinerja perusahaan, hal tersebut dapat dilihat dari laporan keuangannya. Dalam penelitian ini kinerja keuangan diukur menggunakan return on assets (ROA), karena merupakan indikator yang komprehensif, mudah dihitung, dipahami dan merupakan detominator yang dapat diterapkan pada setiap perusahaan. Kinerja keuangan perusahaan berkaitan erat dengan pengukuran dan penilaian kinerja. Pengukuran kinerja (performing measurement) adalah kualifikasi dan efisiensi serta efektivitas perusahaan dalam pengoperasian bisnis selama periode akuntansi. Pengukuran kinerja digunakan perusahaan untuk melakukan perbaikan diatas kegiatan operasionalnya agar dapat bersaing dengan perusahaan lain. Analisis kinerja keuangan merupakan proses pengkajian secara kritis terhadap review data, menghitung, mengukur, menginterprestasi, dan memberi solusi terhadap keuangan perusahaan pada suatu periode tertentu.

Bagi investor, informasi mengenai kinerja keuangan perusahaan dapat digunakan untuk melihat apakah mereka akan mempertahankan investasi mereka di perusahaan tersebut atau mencari alternatif lain. Apabila kinerja perusahaan baik maka nilai usaha akan tinggi. Dengan nilai usaha yang tinggi membuat para investor melirik perusahaan tersebut untuk menanamkan modalnya sehingga akan terjadi kenaikan harga saham. Atau dapat dikatakan bahwa harga saham merupakan fungsi dari nilai perusahaan. Sedangkan bagi perusahaan, informasi kinerja keuangan perusahaan dapat dimanfaatkan untuk hal-hal sebagai berikut:

1. Untuk mengukur prestasi yang dicapai oleh suatu organisasi dalam suatu periode tertentu yang mencerminkan tingkat keberhasilan pelaksanaan kegiatannya. 
2. Selain digunakan untuk melihat kinerja organisasi secara keseluruhan, maka pengukuran kinerja juga dapat digunakan untuk menilai kontribusi suatu bagian dalam pencapaian tujuan perusahaan secara keseluruhan.

3. Dapat digunakan sebagai dasar penentuan strategi perusahaan untuk masa yang akan datang.

4. Memberi petunjuk dalam pembuatan keputusan dan kegiatan organisasi pada umumnya dan divisi atau bagian organisasi pada khususnya.

5. Sebagai dasar penentuan kebijaksanaan penanaman modal agar dapat meningkatkan efisiensi (Kasmir, 2016).

\section{METODE PENELITIAN}

\section{Tempat dan Waktu Penelitian}

Penelitian dilakukan pada Bursa Efek Indonesia dengan mengambil data perusahaan manufaktur di situs resmi Bursa Efek Indonesia (www.idx.co.id), maka penelitian pada kurun waktu 20172019

\section{Populasi dan Sampel \\ Populasi}

Populasi dalam penelitian ini menggunakan perusahaan manufaktur yang terdaftar di Bursa Efek Indonesia periode 2017-2019 sebanyak 160 perusahaan.

\section{Sampel}

Sampel adalah bagian dari jumlah dan karakteristik yang dimiliki oleh populasi. Sampel penelitian dalam penelitian ini adalah perusahaan manufaktur yang terdaftar di Bursa Efek Indonesia selama 3 tahun terakhir dengan periode tahun 2017 sampai tahun 2019.

\section{Teknik Pengumpulan Data}

Teknik pengumpulan sampel dalam penlitiaan ini adalah berdasarkan metode purposive sampling. Metode ini merupakan metode pengumpulaan data sampel yang menyajikan data informasi yang lengkap dan menggunakan pertimbangan atau kriteria tertentu. Setelah dilakukan penyeleksian sampel dengan metode purposive sampling selama periode 2017-2019, maka ada 29 perusahaan yang menjadi sampel dalam penelitian ini, dikali dengan jumlah periode tahun yang digunakan. Dengan begitu sampel yang digunakan peneliti berjumlah sebanyak 29 perusahaan $\times 3$ tahun $=87$ sampel.

\section{Uji Hipotesis}

\section{Uji Normalitas}

Uji normalitas data dilakukan dengan memiliki tujuan untuk menguji apakah di dalam model regresi, variabel penggangu atau residual memiliki distribusi normal (Imam Ghozali, 2013: 160). Model regresi dikatakan baik jika data variabel terdistribusi secara normal. Uji normalitas data dilakukan dengan menggunakan aplikasi SPSS versi 21 dan menggunakan alat uji One Sample Kolomogorov-Smirnov. Pedoman yang digunakan dalam pengambilan keputusan adalah sebagai berikut:

1 Jika nilai Asymp. Sig (2-tailed) lebih besar daripada 0,05, maka data terdistribusi secara normal

2 Jika nilai Asymp. Sig (2-tailed) lebih kecil daripada 0,05, maka data tidak terdistribusi secara normal. 


\section{Uji Multikolinearitas}

Uji multikolinearitas bertujuan untuk menguji apakah model regresi ditemukan adanya korelasi antar variabel bebas (independen) (Imam Ghozali, 2013: 105). Untuk mendeteksi ada atau tidaknya multikolonieritas dalam model regresi dapat dilihat dari nilai tolerance atau variance inflation factor (VIF) dengan kriteria sebagai berikut:

1. Jika nilai tolerance $>0,1$ dan nilai $\mathrm{VIF}<10$, maka tidak terjadi masalah multikolinieritas. Hal ini berarti model regresi dapat dikatakan baik.

2. Jika nilai tolerance $<0,1$ dan nilai $\mathrm{VIF}>10$, maka terjadi masalah multikolinieritas. Hal ini berarti model regresi dapat dikatakan tidak baik.

\section{Uji Autokorelasi}

Uji autokorelasi bertujuan menguji apakah dalam model regresi linear ada korelasi antara kesalahan penggangu pada periode $t$ dengan kesalahan penggangu pada periode $t-1$ (sebelumnya). Autokorelasi muncul karena observasi yang berurutan sepanjang waktu berkaitan satu sama lainnya. Masalah ini timbul karena residual (kesalahan penggangu) tidak bebas dari satu observasi ke observasi lainnya. (Imam Ghozali, 2013: 110). Untuk mendeteksi terjadinya autokorelasi dapat dilakukan dengan pengujian Durbin-Watson Test (Uji DW test) (Imam Ghozali, 2013).

\section{Uji Heteroskedastisitas}

Uji heteroskedastisitas ini digunakan untuk menguji apakah dalam suatu model regresi terjadi ketidaksamaan varian dari residual satu pengamatan ke pengamatan yang lain (Imam Ghozali, 2013). Jika varian dan residual dari satu pengamatan ke pengamatan yang lain tetap, maka disebut homoskedasitisitas sedangkan jika berbeda maka disebut heteroskedastisitas.

\section{Uji Koefisien Determinasi $\left(\mathbf{R}^{2}\right)$}

Koefisien determinasi $\left(\mathrm{R}^{2}\right)$ pada intinya mengukur seberapa jauh kemampuan model dalam menerangkan variasi variabel dependen. Nilai koefisien determinasi adalah antara nol dan satu. Nilai $\mathrm{R}^{2}$ yang kecil berarti kemampuan variabel independen dalam menjelaskan variabelvariabel dependen sangat terbatas. Nilai yang mendekati satu berarti variabel-variabel independen memberikan hampir semua informasi yang dibutuhkan untuk memprediksi variabel dependen. Uji koefisien determinasi $\left(\mathrm{R}^{2)}\right.$ dapat dilakukan secara manual dengan rumus (Imam Ghozali, 2013: 97)

\section{Ketepatan Model (Uji Statistik F)}

Uji $F$ digunakan untuk menguji apakah model regresi dapat digunakan untuk memprediksi variabel dependen. Hipotesis akan diuji dengan menggunakan tingkat signifikansi $(\alpha)$ sebesar $5 \%$ atau 0,05 . Kriteria penerimaan atau penolakan hipotesis akan didasarkan pada nilai probabilitas signifikansi. Jika nilai probabilitas signifikansi $<0,05$, maka hipotesis diterima. Hal ini berarti model regresi dapat digunakan untuk memprediksi variabel bebas. Jika nilai probabilitas signifikansi $>0.05$, maka hipotesis ditolak. Hal ini berarti model regresi tidak dapat digunakan untuk memprediksi variabel terikat (Imam Ghozali, 2013: 98).

\section{Uji Signifikansi Parameter (Uji Statistik t)}

Uji t digunakan untuk menguji apakah variabel bebas secara parsial mempunyai pengaruh terhadap variabel terikat. Hipotesis akan diuji dengan menggunakan tingkat signifikansi $(\alpha)$ sebesar 5\% atau 0,05 . Jika nilai probabilitas signifikansi $<\alpha$, maka dikatakan variabel bebas berpengaruh signifikan terhadap variabel terikat. Jika nilai probabilitas signifikansi $>\alpha$, maka dikatakan variabel bebas tidak berpengaruh signifikan terhadap variabel terikat (Imam Ghozali, 2013: 98). 


\section{Analisis Regresi Linear Berganda}

Pengujian hipotesis dilakukan dengan analisis regresi berganda dilakukan untuk mengetahui pengaruh antarvariabel terikat dan variabel bebas. Pengujian masing masing hipotesis dilakukan dengan menguji masing masing koefisien regresi dengan uji t. Hubungannya dapat diketahui melalui persamaan sebagai berikut :

$$
\mathbf{Y}=\mathbf{a}+\mathbf{b} 1 \mathrm{X} 1+\mathbf{b} 2 \mathrm{X} 2+\mathrm{b} 3 \mathrm{X} 3+\mathrm{b} 4 \mathrm{X} 4+\varepsilon
$$

Keterangan:

Y : Kinerja Keuangan

X1: Pengungkapan Akuntansi Lingkungan

$\mathrm{X} 2$ : Kepemilikan Institusional

X3: Kepemilikan Manajerial

X4: Komite Audit

a : konstanta

b : koefisien Regresi

$\varepsilon$ : Error Term

\section{HASIL PENELITIAAN DAN PEMBAHASAN}

Statistik Deskriptif Variabel Penelitian

Hasil analisis deskriptif di atas menunjukkan bahwa jumlah observasi $(\mathrm{N})$ dari penelitian ini adalah sebanyak 87 observasi. Dari 87 observasi terhadap sampel, Pada variabel pengungkapan akuntansi lingkungan nilai minimum dimiliki oleh PT Charoen Pokhphan Indonesia Tbk (CPIN) tahun 2018 yaitu sebesar 0,18681319. Nilai maksimum dimiliki oleh PT Kimia Farma Tbk (KAEF) dan PT Selamat Sempurna Tbk (SMSM) tahun 2018 dan 2019 sebesar 0,63736264. Dengan nilai rata rata (mean) sebesar 406088 dan standar deviasi sebesar 1337281.

Pada variabel kepemilikan institusional nilai minimum dimiliki oleh PT Kimia Farma Tbk (KAEF) tahun 2018 sebesar 0,04450875. Nilai maksimum dimiliki oleh PT Trisula Internasional Tbk (TRIS) tahun 2019 sebesar 2,66849523. Dengan nilai rata-rata sebesar 613400 dan standar deviasi sebesar 3384466. Variabel ketiga yaitu struktur kepemilikan manajerial yang diperoleh dari perbandingan saham yang dimiliki manajerial dibagi dengan saham yang beredar.

Pada variabel struktur kepemilikan manajerial nilai minimum dimiliki oleh PT Kimia Farma Tbk (KAEF) tahun 2017 sebesar 0,00000. Nilai maksimum dimiliki oleh PT. Sepatu Bata Tbk (BATA) tahun 2017-2019 sebesar 0,82014415. Dengan nilai rata-rata sebesar 169155 dan standar deviasi sebesar 2587438. Pada variabel komite audit ini nilai minimum sebesar 3. Nilai maksimum dimilliki oleh PT Kedawung Setia Industri Tbk (KDSI) tahun 2017-2018 sebesar 5. Dengan nilai rata-rata sebesar 3.16 dan standar deviasi sebesar 0516642. Statistik deskriptif atas sampel penelitian ini dapat dilihat pada tabel 4.

Tabel 4. Deskriptif Statistik Variabel Penelitian Descriptive Statistics

\begin{tabular}{llllll}
\hline & N & Mini & Max & Maen & Std.Deviation \\
\hline CSR & 87 & 1868 & 6374 & 406088 & 1337281 \\
Kepemilikan Institusional & 87 & 0445 & 26685 & 613400 & 3384466 \\
Kepemilikan Manajerial & 87 & 0000 & 8201 & 169155 & 2587438 \\
Komite Audit & 87 & 3 & 5 & 3.16 & .454 \\
ROA & 87 & 0005 & 2273 & 062265 & 0516642 \\
Valid N (listwise) & 87 & & & &
\end{tabular}

Sumber: Data Sekunder diolah, 2021 


\section{Uji Normalitas}

Dalam penelitian ini, uji normalitas yang digunakan adalah uji Kolmogorov-Smirnov dengan melihat nilai Asymp. Sig (2-tailed) dengan probabilitas 0,05. Jika nilai Asymp. Sig (2tailed) lebih besar dari 0,05 maka data terdistribusi normal. Sedangkan jika nilai Asymp. Sig (2tailed) lebih kecil dari 0,05 maka data 1 terdistribusi tidak normal.

Berdasarkan hasil pengujian one sampel kolmogrov smirnov (KS), terlihat bahwa semua variabel memiliki asymp. Sig (2-tailed) lebih besar dari $\alpha=0,05$ yaitu sebesar 0,753. Ini menunjukan semua variabel telah terdistribusi secara normal dengan nilai probabilitas $>0,05$ yang artinya data telah terdistribusi secara normal. Hasil uji normalitas dirangkum dalamTabel 5 berikut ini:

Tabel 5. Hasil Pengujian Normalitas One-Sample Kolmogorov-Smirnov Test

\begin{tabular}{|c|c|c|}
\hline & & Unstandardized residual \\
\hline $\mathrm{N}$ & & 77 \\
\hline Normal Parameters a.b & Mean & 0000000 \\
\hline Std.Deviation & & 02441335 \\
\hline Most Extreme Differences & Absolut & 077 \\
\hline Positive & & 077 \\
\hline Negative & & -063 \\
\hline Kolmogorov-Smirnov $Z$ & & 675 \\
\hline Asymp. Sig. (2-tailed) & & 753 \\
\hline
\end{tabular}

Sumber: Data Sekunder diolah, 2021

\section{Uji Autokorelasi}

Berdasarkan Uji autokorelasi, bahwa model persamaan telah bebas dari masalah autokorelasi, karena pada model persamaan nilai dW lebih besar dari pada dL dan lebih rendah daripada 4-dU yaitu $\mathrm{dU}<\mathrm{dW}<4$-dU sehingga dapat disimpulkan bahwa data bebas autokorelasi. Hasil pengujian autokorelasi pertama pada model variabel bebas dengan jumlah observasi sebanyak 87 , diperoleh nilai dL sebesar 1.5228 , nilai dU sebesar 1.7407 , dan nilai Durbin Watson sebesar 2.200, sehingga disimpulkan bahwa data bebas autokorelasi. Dapat dilita pada Tabel 6 .

Tabel 6. Penilaian DW (Durbin-Watson)

\begin{tabular}{lll}
\hline Hipotesis nol & Keputusan & Jika \\
\hline Tidak ada autokorelasi positif & Tolak & $0<\mathrm{d}<\mathrm{dl}$ \\
Tidak ada autokorelasi positif & Ragu-ragu & $\mathrm{Dl}<\mathrm{d}<\mathrm{du}$ \\
Tidak ada autokorelasi negatif & Tolak & $4-\mathrm{dl}<\mathrm{d}<4$ \\
Tidak ada autokorelasi negatif & Ragu-ragu & $4-\mathrm{du}<\mathrm{d}<4$-dl \\
$\begin{array}{l}\text { Tidak ada autokorelasi positif atau } \\
\text { negatif }\end{array}$ & Tidak ditolak & $\mathrm{Du}<\mathrm{d}<4-\mathrm{du}$ \\
\hline
\end{tabular}

Sumber: Data Sekunder diolah, 2021 
Tabel 7. Hasil Uji Autokorelasi

\begin{tabular}{|c|c|c|c|c|c|c|}
\hline Model & $\mathrm{K}$ & $\mathrm{dL}$ & $D u$ & Durbin-Watson & Kriteria & keterangan \\
\hline 1 & 2 & 1.5228 & 1.7407 & 2.200 & $\mathrm{Du}<\mathrm{dw}<4-\mathrm{du}$ & Bebas autokorelasi \\
\hline
\end{tabular}

Uji Multikolinearitas

Tabel 8. Hasil Uji Multikolinearitas

\begin{tabular}{llc}
\hline Model & $\begin{array}{l}\text { Collinearity Statistick } \\
\text { Tolerance }\end{array}$ & VIF \\
\hline 1 (Constant) & & 1.042 \\
Pengungkapan Akuntansi Lingkungan & .959 & 1.166 \\
Kepemilikan Institusional & & 1.184 \\
Kepemilikan Manajerial & .858 & 1.024 \\
Komite Audit & .845 & \\
& .977 & \\
\hline
\end{tabular}

Sumber: Data Sekunder diolah, 2021

Berdasarkan tabel 8 dapat dilihat bahwa tidak terdapat model persamaan yang terkena masalah multikolinearitas. Variabel independen pengungkapan akuntansi lingkungan pada hipotesis ke-1 memiliki nilai tolerance 0,959 nilai tersebut $>0,1$. Selanjutnya nilai VIF sebesar 1.042 nilai tersebut $<10$, maka pengungkapan akuantansi lingkungan terbebas dari masalah multikolinearitas.

Untuk variabel kedua pada hipotesis ke-2 memiliki nilai tolerance 0,858 nilai tersebut $>$ 0,1 , selanjutnya nilai VIF sebesar 1.166 nilai tersebut $<10$, maka terbebas dari masalah multikolinearitas. Sedangkan untuk vaiabel ketiga yaitu struktur kepemilikan manajerial pada hipotesis ke-3, proksi ini memiliki nilai tolerance 0,845 nilai tersebut $>0,1$, selanjutnya nilai VIF sebesar 1.184 nilai tersebut $<10$, maka struktur kepemilikan manajerial terbebas dari masalah multikolinearitas. pada hipotesis ke-4, proksi ini memiliki nilai tolerance 0,977 nilai tersebut $>0,1$, selanjutnya nilai VIF sebesar 1.024 nilai tersebut $<10$, maka komite audit terbebas dari masalah multikolinearitas.

\section{Uji Heterokedastisitas}

Jika koefisien korelasi semua variabel terhadap residual $>0,05$ dapat disimpulkan bahwa model regresi tidak terjadi heteroskedastisitas. Berdasarkan tabel 4.6 diatas terlihat bahwa nilai pengungkapan akuntansi lingkungan memiliki nilai signifikansi sebesar 0,901>0,05, maka model regresi untuk variabel pengungkapan akuntansi lingkungan bebas heteroskedastisitas. Nilai variabel kepemilikan institusional memiliki nilai signifikansi sebesar 0,158 $>0,05$, maka model regresi untuk variabel kepemilikan institusional bebas heteroskedastisitas. Sedangkan untuk nilai struktur kepemilikan manajerial memiliki nilai signifikansi sebesar $0.219>0,05$, maka model regresi untuk variabel struktur kepemilikan manajerial bebas heteroskedastisitas.

Nilai variabel komite audit memiliki nilai signifikansi sebesar 0,949>0,05, maka model regresi untuk variabel komite audit bebas heteroskedastisitas Maka, dapat disimpulkan bahwa keseluruhan model pada penelitian ini bebas dari masalah heteroskedastisitas. Hasil uji heteroskedastisitas pada tabel 9 dibawah ini: 
Tabel 9. Hasil Uji Heteroskedatisitas

\begin{tabular}{llllll}
\hline Model & Unstandardized & & $\begin{array}{l}\text { Standardizer } \\
\text { coeffcients } \\
\text { Beta }\end{array}$ & T & Sig \\
& $\mathrm{B}$ & $\begin{array}{l}\text { Std. } \\
\text { Error }\end{array}$ & & & \\
\hline $\begin{array}{l}\text { 1 (Constant) } \\
\begin{array}{l}\text { Pengungkapan akuntansi } \\
\text { lingkungan }\end{array}\end{array}$ & -022 & .007 & -015 & 3.015 & .004 \\
$\begin{array}{l}\text { Kepemilikan institusional } \\
\text { Kepemilikan manajerial }\end{array}$ & -009 & .013 & -178 & -125 & .901 \\
Komite audit & -014 & .006 & -156 & -1.425 & .158 \\
& 0000 & .011 & -156 & -1.241 & .219 \\
& & .005 & .007 & .064 & 949
\end{tabular}

Sumber: Data Sekunder diolah, 2021

Analisis Regresi Linier Berganda

Penelitian ini menggunakan analisis regresi linier berganda dengan program SPSS. Model persamaan regresi berganda yang akan diteliti dalam pengujian hipotesis adalah sebagai berikut:

$$
\text { Model : } \begin{array}{r}
\mathbf{Y}=\boldsymbol{\alpha}+\boldsymbol{\beta 1} \mathbf{X 1}+\boldsymbol{\beta} 2 \mathbf{X 2}+\boldsymbol{\beta 3} \mathbf{X 3}+\boldsymbol{\beta 4 X 4 + \mathbf { e }} \\
=(0.038)+0.019+0.000+0.036+(-0.022)+\mathrm{e}
\end{array}
$$

Tabel 10. Hasil Uji Linear Berganda

\begin{tabular}{|c|c|c|c|c|c|}
\hline Model & $\begin{array}{l}\text { Unstandardized } \\
\text { Coefficients } \\
\text { B }\end{array}$ & Std.error & $\begin{array}{l}\text { Standardized } \\
\text { Coefficients } \\
\text { Beta }\end{array}$ & $\mathrm{T}$ & Sig \\
\hline 1 ( Constant) & .038 & .011 & & 3.339 & .001 \\
\hline $\begin{array}{l}\text { Pengungkapan } \\
\text { akuntansi } \\
\text { lingkungan }\end{array}$ & .019 & .021 & .102 & .919 & .361 \\
\hline $\begin{array}{l}\text { Kepemilikan } \\
\text { institusional }\end{array}$ & .000 & .010 & .003 & .025 & .980 \\
\hline $\begin{array}{l}\text { Kepemilikan } \\
\text { manajerial }\end{array}$ & .036 & .017 & .246 & 2.078 & .041 \\
\hline Komite audit & -.022 & .008 & -.289 & -2.621 & .011 \\
\hline
\end{tabular}

a.Dependent Variable: LAGY

Sumber: Data Sekunder diolah, 2021

Berdasarkan persamaan regresi linier berganda tersebut, maka dapat dijabarkan sebagai berikut : Nilai konstanta sebesar 0,038 dapat diartikan bahwa apabila variabel independen, yaitu pengungkapan akuntansi lingkungan, kepemilikan institusional, kepemilikan manajerial, komite audit dianggap konstan (bernilai 0). Koefesien untuk pengungkapan akuntansi lingkungan perusahaan sebesar 0,019 artinya apabila pengungkapan akuntansi lingkungan mengalami kenaikan 1 sedangkan variabel lainnya dianggap konstan (bernilai 0 ). Koefesien untuk kepemilikan istitusional sebesar 0,000 artinya apabila ukuran perusahaan mengalami kenaikan 1 sedangkan variabel lainnya dianggap konstan (bernilai 0). Koefesien untuk struktur kepemilikan manajerial sebesar 0,36 artinya apabila ukuran perusahaan mengalami kenaikan 1 sedangkan variabel lainnya dianggap konstan (bernilai 0). 
Uji Kelayakan Model (F)

Hasil uji F dapat dilihat pada tabel 4.8 sebagai berikut :

Tabel 11. Hasil Uji F

ANOVA b

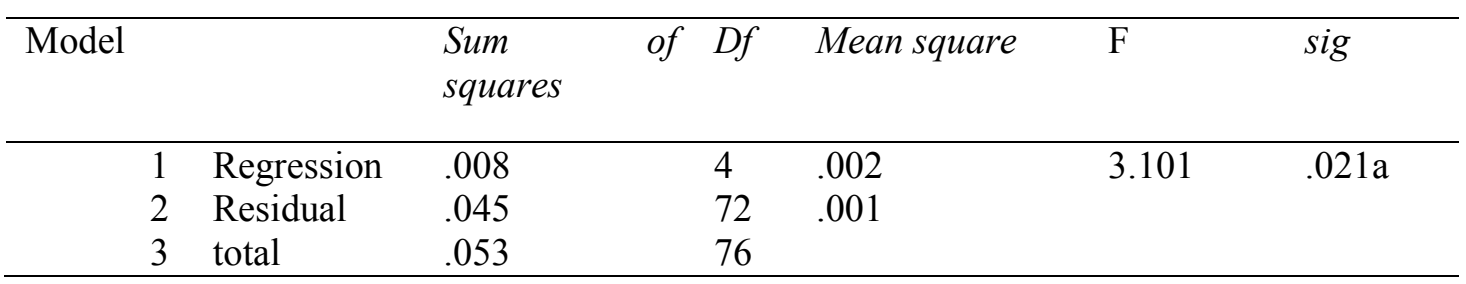

Sumber: Data Sekunder diolah, 2021

Berdasarkan tabel 11 hasil uji $\mathrm{F}$ menunjukkan bahwa nilai $\mathrm{F}$ hitung yang terdapat dalam tabel ANOVA yaitu sebesar 3.101 dengan signifikansi 0,21. Sementara Ftabel dari df (3:70) sebesar 2,74 sehingga Fhitung > Ftabel yakni 3.101 >2,74 dan nilai signifikan juga lebih kecil dari probabilitas 5\%. Sehingga dapat disimpulkan bahwa model regresi dalam penelitian ini fit dan berpengaruh secara simultan atau bersama-sama dari seluruh variabel independen yaitu pengungkapan akuntansi lingkungan, kepemilikan institusional, struktur kepemilikan manajerial dan komite audit terhadap kinerja keuangan.

\section{Uji Koefisien Determinasi (R2)}

Nilai koefisien determinasi adalah antara nol dan satu. Jika R2 memiliki nilai yang kecil berarti kemampuan variabel independen dalam menjelaskan variasi dependen sangat terbatas. Hasil uji koefisien determinasi (R2) dapat dilihat pada tabel 4.9 sebagai berikut :

Tabel 12. Hasil Uji Koefisien Determinasi Model Summary

\begin{tabular}{llllll}
\hline Model & $\mathrm{R}$ & $R$ Square & $\begin{array}{l}\text { Adjusted } \\
\text { Square }\end{array}$ & $R$ & $\begin{array}{l}\text { Std. Errror of the } \\
\text { estimate }\end{array}$ \\
\hline 1 & .383 & .147 & .100 & .02508 & 2.200
\end{tabular}

a. Predictors: (Constant, LAGX4, LAGX3, LAGX2, LAGX1

b. Dependent Variabel: LAGY

Sumber: Data Sekunder diolah, 2021

Berdasarkan data diatas adapun analisis determinasi berganda diketahui presentase pengaruh variabel bebas terhadap variabel terikat yang ditunjukan dengan nilai Adjusted $R$ Square sebesar 0.100 maka koefisien determinasi berganda $0,100 \times 100 \%=10 \%$ dan sisanya $100 \%-10 \%=90 \%$. Hal ini berarti naik turunnya variabel terikat yaitu kinerja keuangan dipengaruhi oleh variabel bebas yaitu pengungkapan akuntansi lingkungan, kepemilikan institusional, kepemilikan manajerial dan komite audit sebesar 10\%. Sedangkan sisanya sebesar $90 \%$ dipengaruhi oleh variabel lain yang tidak diteliti dalam penelitian ini.

\section{Uji Parsial (Uji t)}

Uji statistik t pada dasarnya menunjukkan seberapa jauh pengaruh satu variabel independen secara individual dalam menerangkan variabel dependen (Imam, 2013). Pada uji t statistik t, nilai $t$ hitung akan dibandingkan dengan $t$ table. Apabila $t$ hitung $>t$ tabel atau probabilitas $<$ tingkat signifikansi $(\mathrm{Sig}<0,05)$ maka variabel independen tersebut berpengaruh terhadap variabel dependen. Hasil uji parsial (uji t) dapat dilihat pada tabel 13 sebagai berikut: 
Tabel 13. Hasil Uji Parsial (Uji t)

Coefficients a

\begin{tabular}{|c|c|c|c|c|c|}
\hline Model & $\begin{array}{l}\text { Unstandardized } \\
\text { Coefficients } \\
\text { B }\end{array}$ & Std.error & $\begin{array}{l}\text { Standardized } \\
\text { Coefficients } \\
\text { Beta }\end{array}$ & $\mathrm{t}$ & sig \\
\hline 1 ( Constant) & .038 & .011 & & 3.339 & .001 \\
\hline $\begin{array}{l}\text { Pengungkapan } \\
\text { akuntansi } \\
\text { lingkungan }\end{array}$ & .019 & .021 & .102 & .919 & .361 \\
\hline $\begin{array}{l}\text { Kepemilikan } \\
\text { ainstitusional }\end{array}$ & .000 & .010 & .003 & .025 & .980 \\
\hline $\begin{array}{l}\text { Kepemilikan } \\
\text { manajerial }\end{array}$ & .036 & .017 & .246 & 2.078 & .041 \\
\hline Komite audit & -.022 & .008 & -.289 & -2.621 & .011 \\
\hline
\end{tabular}

a. Dependent Variabel : LAGY

Data Sekunder diolah, 2021

\section{PEMBAHASAN}

Pengaruh Pengungkapan Akuntansi Lingkungan terhadap Kinerja Keuangan

Dari analisis yang telah dilakukan, dapat diperoleh pengungkapan akuntansi lingkungan secara individual tidak berpengaruh terhadap kinerja keuangan pada perusahaan manufaktur yang terdaftar di BEI 2017-2019. Uji regresi pengungkapan akuntansi lingkungan yang telah dilakukan pada hipotesis pertama menunjukan koefisien regresi bernilai sebesar 0,019 , nilai $t$ sebesar 0,919 dan nilai signifikansi sebesar 0,361 (tingkat signifikansi > 0,05). Yang menyatakan bahwa pengungkapan akuntansi lingkungan tidak berpengaruh terhadap kinerja keuangan, hal ini ditunjukkan dengan signifikansi sebesar 0,361 dimana lebih besar dari 0,05.

Hasil ini sejalan dengan penelitian yang dilakukan Jayanti (2015) terdapat pengaruh negatif signifikan dari pengungkapan akuntansi lingkungan terhadap kinerja keuangan yang diproksikan dengan Return On Assets (ROA). Artinya bahwa hasil penelitian ini Pengungkapan Akuntansi Lingkungan perusahaan yang tidak mempengaruhi Kinerja keuangan. Hal ini menunjukkan bahwa Pengungkapan Akuntansi Lingkungan bukan merupakan prediktor yang dapat mempengaruhi kinerja keuangan dalam suatu perusahaan. Tingkat signifikansi sebesar 0,361 (lebih besar dari $\alpha=0,05$ ). Hasil ini menunjukkan bahwa Pengungkapan Akuntansi Lingkungan tidak berpengaruh terhadap kinerja keuangan pada perusahaan yang terdaftar di Bursa Efek Indonesia. Artinya Pengungkapan Akuntansi Lingkungan tidak menjamin suatu perusahaan untuk menerapkan kinerja keuangan. Hal ini menunjukkan terdapat faktor lain yang lebih berperan dalam mempengaruhi kinerja keuangan. Menurut (Yusmaniarti, Yusmaniarti, 2020) dalam penelitiannya menjelaska bahwa Return On Asset merupakan faktor penting yang mempengaruhi kinerja keuangan perusahaan.

\section{Pengaruh Kepemilikan Institusional Terhadap Kinerja Keuangan}

Dari analisis yang telah dilakukan, dapat diperoleh kepemilikan institusional secara Individual tidak berpengaruh terhadap kinerja keuangan pada perusahaan manufaktur yang terdaftar di BEI 2016-2018. Uji regresi kepemilikan institusional yang telah dilakukan pada hipotesis kedua menunjukan koefisien regresi bernilai sebesar 0,000 , nilai t sebesar 0,25 dan nilai signifikansi sebesar 0,980 (tingkat signifikansi $>0,05$ ). Yang menyatakan bahwa kepemilikan institusional tidak berpengaruh terhadap kinerja keuangan, hal ini ditunjukkan dengan signifikansi sebesar 0,980 dimana lebih besar dari 0,05. Hasil ini sejalan dengan penelitian yang dilakukan Ardiyani (2010) dalam penelitiannya menyatakan bahwa kepemilikan institusional tidak berpengaruh secara signifikan terhadap kinerja perusahaan yang berarti 
bahwa kepemilikan instutisional tidak mampu untuk mendorong peningkatan kinerja perusahaan.

\section{Pengaruh Kepemilikan Manajerial Terhadap Kinerja Keuangan}

Dalam statistik terlihat hanya beberapa manajerial yang memiliki saham pada bank syariah tersebut, Memang dalam bank Syariah berbanding terbalik dengan kepemilikan institusional dikarenakn saham yang ada di bank syariah menginduk dengan bank umum konevensional sebelumnya. Dari analisis yang telah dilakukan, dapat diperoleh Struktur Kepemilikan Manajerial secara individual berpengaruh positif dan signifikan terhadap Kinerja keuangan pada perusahaan manufaktur yang terdaftar di BEI 2017-2019.

Uji regresi yang telah dilakukan pada hipotesis ketiga menunjukan koefisien regresi bernilai sebesar 036, nilai t sebesar 2.078 dan nilai signifikansi sebesar 0,041 (tingkat signifikansi $<0,05)$. Yang menyatakan bahwa Struktur Kepemilikan Manajerial berpengaruh positif dan signifikan terhadap kinerja keuangan, hal ini ditunjukkan dengan signifikansi sebesar 0,041 dimana lebih kecil dari 0,05. Ini berarti struktur kepemilikan manajerial merupakan faktor yang berpengaruh signifikan dan positif terhadap kinerja keuangan. Hal ini sejalan dengan penelitian yang dilakukan oleh Yudha, dkk (2014) menunjukkan bahwa pengaruh corporate governance dalam hal kepemilikan manajerial berpengaruh terhadap kinerja keuangan perusahaan. Christiawan dan Tarigan (2007) juga mengungkapkan bahwa perusahaan dengan kepemilikan manajerial rata-rata kinerja perusahaannya lebih baik dibandingkan dengan perusahaan tanpa kepemilikan manajerial.

\section{Pengaruh Komite Audit Terhadap Kinerja Keuangan}

Dari analisis yang telah dilakukan, dapat diperoleh komite audit secara individual berpengaruh positif dan signifikan terhadap Kinerja keuangan pada perusahaan manufaktur yang terdaftar di BEI 2017-2019. Uji regresi yang telah dilakukan pada hipotesis ketiga menunjukan koefisien regresi bernilai sebesar -022 , nilai t sebesar -2.621 dan nilai signifikansi sebesar 0,011 (tingkat signifikansi $<0,05$ ). Yang menyatakan bahwa komite audit berpengaruh positif dan signifikan terhadap kinerja keuangan, hal ini ditunjukkan dengan signifikansi sebesar 0,011 dimana lebih kecil dari 0,05. Ini berarti komite audit merupakan faktor yang berpengaruh signifikan dan positif terhadap kinerja keuangan. Hal ini sejalan dengan penelitian Arifani (2012) bahwa komite audit mempunyai pengaruh terhadap kinerja keuangan. Hal ini mengindikasikan bahwa dengan dibentuknya komite audit mampu untuk mengawasi manajemen dalam meningkatkan kinerja keuangannya. Begitu penelitian yang dilakukan oleh (Yusmaniarti, Yusmaniarti, 2020)yang menyimpulkan bahwa komite audit berpengaruh signifikan positif meningkatkan kinerja keuangan yang di ukur dengan Return on Equity (ROE).

\section{Pengaruh Pengungkapan Akuntansi Lingkungan, Kepemilikan Institusional, Manajerial, Komite Audit Secara Simultan Terhadap Kinerja Keuangan.}

Hasil pengujian hipotesis mengenai pengaruh pengungkapan akuntansi lingkungan, kepemilikan institusional, kepemilikan manajerial, komite audit secara simultan terhadap kinerja keuangan menunjukkan nilai hasil Uji $\mathrm{F}$ diperoleh signifikansi 0,021 lebih kecil dari 0,05 Sehingga dapat disimpulkan bahwa model regresi dalam penelitian ini fit dan berpengaruh secara simultan atau bersama-sama dari seluruh variabel independen yakni pengungkapan akuntansi lingkungan, kepemilikan institusional, kepemilikan manajerial, komite audit terhadap variabel dependen kinerja keuangan. Hasil ini sejalan dengan penelitian yang dilakukan (Ekaputri dkk, 2018) Variabel Pengungkapan Akuntansi Lingkungan (X1), Mekanisme Good Corporate Governance (X2), berpengaruh secara simultan terhadap Kinerja Keuangan(Y).(Yusmaniarti, Yusmaniarti; Setiorini, 2019) 


\section{KESIMPULAN DAN SARAN}

\section{Kesimpulan}

Berdasarkan hasil yang diperoleh dari pengelolahan dan analisis data dengan bantuan alat SPSS 16.0, maka dapat diambil kesimpulan sebagai berikut :

1. Pengungkapan akuntansi lingkungan tidak berpengaruh terhadap kinerja keuangan. Hal ini ditunjukkan dengan signifikansi sebesar 0,361 dimana lebih besar dari 0,05 .

2. Kepemilikan institusional tidak berpengaruh terhadap kinerja keuangan. Hal ini ditunjukkan dengan signifikansi sebesar 0,980 dimana lebih besar dari 0,05.

3. Kepemilikan manajerial berpengaruh positif dan signifikan terhadap kinerja keuangan. Hal ini ditunjukkan dengan signifikansi sebesar 0,041 dimana lebih kecil dari 0,05.

4. Komite audit berpengaruh positif dan signifikan terhadap kinerja keuangan. Hal ini ditunjukkan dengan signifikansi sebesar 0,011 dimana lebih kecil dari 0,05.

5. Secara simultan pengungkapan akuntansi lingkungan, kepemilikan institusional, kepemilikan manajerial dan komite audit terbukti berpengaruh terhadap kinerja keuangan pada perusahaan Manufaktur yang terdaftar di Bursa Efek Indonesia tahun 2017-2019. Hal ini ditunjukkan dengan signifikansi sebesar 0,021 dimana lebih kecil dari 0,05.

\section{Saran}

Berdasarkan keterbatasan yang terdapat pada penelitian ini, maka peneliti mengajukan beberapa saran dalam upaya perbaikan penulisan untuk penelitian selanjutnya antara lain:

1. Bagi investor dapat melakukan analisa laporan keuangan sehubungan dengan keputusan dalam menanamkan modal kepada perusahaan dengan melihat dari manajemen sehingga dapat mengenali tanda-tanda awal kebangkrutan, kemudian mengantisipasi kemungkinan tersebut

2. Sampel yang digunakan pada penelitian ini hanya terfokus pada perusahaan manufaktur yang terdaftar di Bursa Efek Indonesia (BEI), sehingga tidak dapat digeneralisasikan pada jenis industri lain. Untuk penelitian selanjutnya disarankan memperbesar sampel penelitian tidak hanya terbatas pada perusahaan manufaktur saja, tapi juga pada perusahaan sektor lain seperti pertambangan, perkebunan, keuangan dan non keuangan.

3. Peneliti yang akan datang hendaknya menambahkan variabel lain yang dapat mempengaruhi.

4. Untuk penelitian selanjutnya diharapkan memperpanjang periode waktu

5. penelitian (time series).

\section{DAFTAR PUSTAKA}

Andri Veno. (2015). Pengaruh Corporate Governance Terhadap Kinerja Perusahaan Manufaktur. Jurnal Ekonomi Dan Bisnis Airlangga, 19(1), 95-112.

https://doi.org/10.20473/jeba.v28i12018.57-73

\section{Arifani, R. (2012). No PENGARUH GOOD CORPORATE GOVERNANCE TERHADAP KINERJA KEUANGAN PERUSAHAAN.}

Ekaputri, M. N. R. Lestari, R., Rosdiana, Y., \& Fitriah, E. (2018). Kontribusi Pengungkapan Akuntansi Lingkungan Dan Mekanisme GCG Terhadap Kinerja Keuangan.

Handayati, P. (2017). Analisis Kinerja Lingkungan Dan Mekanisme Gcg Terhadap Pengungkapan Pertanggungjawaban Sosial. Jurnal Akuntansi Aktual, 4(1), 58-68. https://doi.org/10.17977/um004v4i12017p058

Sri Rokhlinasari. (2016). Teori-Teori dalam Pengungkapan Informasi Corporate Social Responbility Perbankan Oleh: 1-11. 
Suartana, I. (2010). Akuntansi Lingkungan Dan Triple Bottom Line Accounting: Paradigma Baru Akuntansi Bernilai Tambah. Bumi Lestari, 10(1).

Tarmizi, R. (2012). ANALISIS PENGUNGKAPAN AKUNTANSI LINGKUNGAN TERHADAP PERTANGGUNGJAWABAN SOSIAL INDUSTRI KIMIA. Journal of Chemical Information and Modeling, 3(1), 1689-1699.

Yusmaniarti, Yusmaniarti; Setiorini, H. P. (2019). Influence PENGARUH GOOD CORPORATE GOVERNANCE, PROFITABILITAS, DAN LEVERAGE TERHADAP NILAI PERUSAHAAN PADA PERUSAHAAN PROPERTY DAN REAL ESTATE INDONESIA. Bilancia : Jurnal Ilmiah Akuntansi, 3(4), 406-418. https://doi.org/10.4018/ijpada.2016010103

Yusmaniarti, Yusmaniarti, A. B. (2020). Pengaruh Penerapan Good Corporate Governance, Independensi Auditor Dan Kualitas Audit Terhadap Nilai Perusahaan. Jurnal Sains Manajemen Dan Bisnis Indonesia, 10(1), 50-67. 